\title{
ASPECTS OF SACRAMENTO PIKEMINNOW BIOLOGY IN NEARSHORE HABITATS OF THE SACRAMENTO-SAN JOAQUIN DELTA, CALIFORNIA
}

\author{
Matthew L. Nobriga ${ }^{1}$, Frederick Feyrer ${ }^{1}$, and Randall D. Baxter ${ }^{2}$
}

\begin{abstract}
Aвstract.-We documented distribution, relative abundance, diet composition, and body condition of Sacramento pikeminnow Ptychocheilus grandis during 2001 and 2003 at 5 sites in the Sacramento-San Joaquin Delta, California. Sacramento pikeminnow densities in nearshore habitats were higher in 2003 than 2001. In both years, spatial distribution of beach seine densities was similar. There were no significant differences in density among sampling sites except for the southernmost site where the catch was near zero. Based on rotary screw-trap data from a 6th site, we found relative abundance of Sacramento pikeminnow entering the Delta via an artificial floodplain was positively correlated with flow. Most individuals collected using all 3 gear types were age 1 or older, and appeared to grow quickly based on data from previous studies. Sacramento pikeminnow had diverse diets composed of freshwater and estuarine invertebrate and fish taxa. Incidence of piscivory was only $2 \%$ of the diet of individuals $<150 \mathrm{~mm}$, but increased to $50 \%$ for fish over $150 \mathrm{~mm}$. No salmonids were observed in foregut contents during the study. In both years body condition declined abruptly in July. Our results suggest Sacramento pikeminnow are more common in the turbid, tidal freshwater habitats of the Delta than was previously recognized. Stream flows may play an important role in moving juvenile Sacramento pikeminnow into the Delta from upstream areas. Similar to northern pikeminnow P. oregonensis, but in seeming contrast to endangered Colorado pikeminnow P. lucius, the present study showed that Sacramento pikeminnow can be successful in altered habitats.
\end{abstract}

Key words: Sacramento pikeminnow, Ptychocheilus grandis, Sacramento-San Joaquin Delta, habitat use, diet composition, condition factor, Cyprinidae.

The pikeminnows (Genus: Ptychocheilus) are unique among North American cyprinids due to their large size and ecological roles as apex predators (Carney and Page 1990). Two Ptychocheilus spp. are native to California. The Colorado pikeminnow P. lucius is endangered and presumed extinct within California waters (Moyle 2002). In contrast, the Sacramento pikeminnow $P$. grandis is common, widely distributed, and even considered a pest in some locations. The natural distribution of Sacramento pikeminnow includes middle and low elevation streams of the Sacramento-San Joaquin River system, the Clear Lake basin, and the PajaroSalinas and Russian River systems (Taft and Murphy 1950). In addition, Sacramento pikeminnow have been introduced into the Eel River, tributaries of Morro Bay, and some southern California reservoirs (Moyle 2002). Most field studies of Sacramento pikeminnow, or the fish communities of which they were part, have examined their ecology in lotic habitats or reservoirs (e.g., Vondracek et al. 1989, Brown 1990, Brown and Moyle 1991, Merz and Van- icek 1996, Brown and Ford 2002, Moyle et al. 2003). Life history data for Ptychocheilus spp. in tidal systems have not been documented in detail, though pikeminnow species are known to occur in tidal low-salinity and fresh-river reaches (Taft and Murphy 1950, Turner 1966, Bottom and Jones 1990, Matern et al. 2002). Perhaps due to limited documentation of catches from tidal habitats, Sacramento pikeminnow has been reported as uncommon in the largest tidal freshwater system within its range, the Sacramento-San Joaquin Delta, hereafter "Delta" (Moyle 2002).

During 2001 and 2003, we studied fish use of nearshore habitats in the Delta (Fig. 1). Life history data for Sacramento pikeminnow in the Delta are lacking. Here, we address 4 basic life history questions regarding use of this tidal freshwater habitat: (1) When and where do Sacramento pikeminnow occur, and how relatively abundant are they? (2) Does stream inflow influence use of the Delta as rearing habitat? (3) What types of prey are eaten? (4) Does body condition vary spatially or temporally?

${ }^{1}$ California Department of Water Resources, Aquatic Ecology Section, 3251 S Street, Sacramento, CA 95816.

${ }^{2}$ California Department of Fish and Game, Central Valley/Bay-Delta Branch, 4001 North Wilson Way, Stockton, CA 95205. 


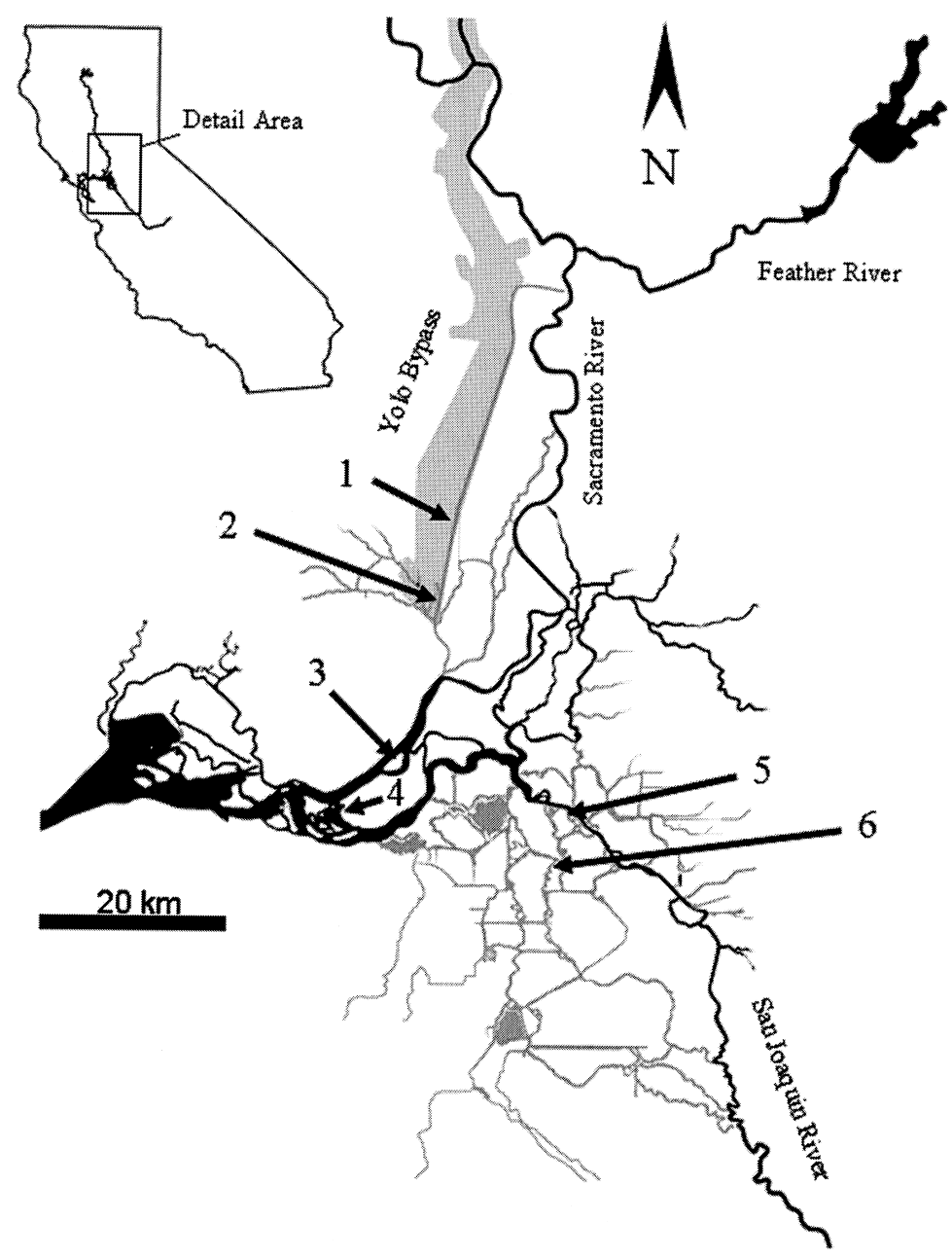

Fig. 1. The Sacramento-San Joaquin Delta showing sampling site locations. 1 = Yolo Bypass rotary screw-trap site, $2=$ Liberty Island, $3=$ Sacramento River, $4=$ Sherman Lake, $5=$ San Joaquin River, $6=$ Mildred Island.

This information provides new insight into the life history of Sacramento pikeminnow, its role as a predator of special-status fishes such as Chinook salmon Oncorhyncus tschawytscha, and the restoration needs of native fishes in the Delta and its watershed.

\section{Materials AND Methods}

\section{Study Area}

The Sacramento-San Joaquin Delta (Fig. 1) is the landward limit of the San Francisco Estuary and a water supply nexus for much of California's population (Arthur et al. 1996). The Delta comprises an extensive network of tidallyinfluenced channels that provide nearly 1100 $\mathrm{km}^{2}$ of potential habitat for Sacramento pikeminnow and other fishes. It receives freshwater runoff from approximately 100,000 km² (40\%) of California's surface area. Most natural runoff occurs during winter and spring (DecemberMay), but a significant proportion of natural runoff is captured in numerous reservoirs located throughout the Sacramento-San Joaquin watershed. Reservoir releases from the Sacramento River maintain year-round freshwater conditions in the Delta. For instance, data from the California Department of Fish and Game indicate that, during this study, specific conductance did not exceed $4499 \mu \mathrm{s}$. $\mathrm{cm}^{-1}$ (approximately 2\% oceanic salinity) at Sherman Lake, our most seaward site. The 
maintenance of freshwater conditions yearround supports regional agriculture and freshwater exports for agriculture and urban users to the south (Arthur et al. 1996, Kimmerer 2002). A highly variable average of 4.5 billion $\mathrm{m}^{3} \cdot \mathrm{yr}^{-1}$ of fresh water is exported from the southern Delta $(\sim 17 \%$ of annual outflow to the estuary; Kimmerer 2002). Water exports substantially affect estuarine hydrodynamics, water quality, and fisheries (Arthur et al. 1996, Bennett and Moyle 1996, Kimmerer 2002).

We sampled fishes monthly (March-October 2001 and 2003) at 5 nearshore sites (Fig. 1). These sampling sites were chosen for logistical reasons; all contained substantial amounts of shoreline that could be efficiently sampled with a beach seine. The sampling sites included shoals $<1.5 \mathrm{~m}$ deep located along river channel edges or along levees within former agricultural "islands" that were subsequently flooded and not reclaimed (see Grimaldo et al. 2004 for a detailed description of the latter habitat type). Fishes were collected using a beach seine and a gill net. All Sacramento pikeminnow were counted and measured for fork length $(\mathrm{mm})$. Two persons, transported in a small, shallow draft boat, entered the water offshore of a sample area and seined fish using a $30 \times 1.8-\mathrm{m}$ (3.2-mm mesh) beach seine. Each month, 2-8 seine hauls were made per site. One site was sampled per day, so 5 days were needed to complete each month's sampling. We collected samples during daylight, usually during a flooding tide in the afternoon. Estimates of volume swept $\left(\mathrm{m}^{3}\right)$ by the beach seine were made using the formula,

$$
\mathrm{V}=\left[\mathrm{OD}\left(\mathrm{L}_{1}+\mathrm{L}_{2}\right)\right] / 4
$$

where $\mathrm{O}$ is the perpendicular distance from shore at the initiation of the haul, $\mathrm{L}_{1}$ is the length of beach seine deployed parallel to shore at the initiation of the haul, $\mathrm{L}_{2}$ is the distance remaining between the seiners when they reached the shoreline, and D is the water depth at the initiation of the haul. All measurements except water depth were estimated to the nearest $0.1 \mathrm{~m}$ using a tape measure after the net was brought to shore. Initial water depth $( \pm 0.1 \mathrm{~m})$ was estimated using a ruler marked on the beach seine brails. Mean depths at the start of beach seine hauls averaged about $1 \mathrm{~m}$ at all sites.
Deeper water near the beach seine sites was sampled using a gill net $(60 \times 2.4 \mathrm{~m}$ with randomized graded-mesh panels of 51-102$\mathrm{mm}$ stretch mesh). The gill net was set parallel to shore for 20-30 minutes, 2-6 times per visit, in water approximately $2-4 \mathrm{~m}$ deep. We used a parallel-to-shore deployment to minimize incidental captures of offshore-oriented species of concern (salmonids and sturgeon) and short deployment times to minimize mortality of all species. Most sampling was conducted around sunset to coincide with active foraging periods of piscivores including Sacramento pikeminnow (Brown 1990).

To determine whether river flow influenced the dispersal of Sacramento pikeminnow into our study area, we examined longer-term data from rotary screw-trap sampling in the Yolo Bypass. The rotary screw-trap sampling methods were described by Sommer et al. (2004). We used linear regression to test for an effect of log-transformed Yolo Bypass flow (USGS gauge at Woodland, CA) on Sacramento pikeminnow catch per unit effort (fish $\cdot 24 \mathrm{hr}^{-1}$ ) in the Yolo Bypass Toe Drain (Fig. 1). Both variables were calculated for the period 1 January through 30 June 1998-2004.

We subsampled up to 10 Sacramento pikeminnow per gear per sampling day for examination of body condition and feeding habits. Whole fish up to $306 \mathrm{~mm}$ were preserved in $10 \%$ formaldehyde. In the laboratory they were remeasured. Preservation times varied from approximately 2 weeks to 4 months. Prior to dissection for gut content analysis, the fish were weighed to the nearest $0.01 \mathrm{~g}$ using an electronic balance. Their foreguts were then removed and all contents were identified to lowest practicable taxon. For Sacramento pikeminnow larger than $306 \mathrm{~mm}$, the entire digestive tract was removed in the field and preserved as above; only foregut contents were examined in the laboratory. Diet composition was summarized as frequency of occurrence. An initial visual inspection of diet composition data elucidated a noticeable change in frequency of piscivory between Sacramento pikeminnow $<150 \mathrm{~mm}$ and $>150 \mathrm{~mm}$. Therefore, we summarized the diet composition of these size classes separately.

We summarized beach seine catch of Sacramento pikeminnow as frequency of occurrence and density (fish $\cdot 10,000 \mathrm{~m}^{-3}$ ). Each metric was ranked relative to other species collected. For 
each year, we plotted Sacramento pikeminnow lengths versus date of collection to qualitatively evaluate fish sizes vulnerable to our 2 gear types. This allowed us to make coarse assessments of age structure. Based on these data, we determined that beach seine efficiency was poor for Sacramento pikeminnow $\geq 200 \mathrm{~mm}$. Declining beach seine efficiency with increasing fish size is a well-documented phenomenon (Bayley and Herendeen 2000). Based on these results, we excluded Sacramento pikeminnow larger than $200 \mathrm{~mm}$ from statistical analysis of the beach seine data. Natural logtransformed densities of Sacramento pikeminnow $<200 \mathrm{~mm}$ were tested for differences among years and sites using 2-way ANOVA. For Sacramento pikeminnow $\geq 200 \mathrm{~mm}$, we limited ourselves to a nonstatistical assessment of interannual and spatial trends in relative abundance. We used a combination of beach seine and gill net catches of these larger fish to calculate annual, site-specific abundance indices based on the percentage of monthly samples in which at least 1 individual $\geq 200 \mathrm{~mm}$ was collected.

We analyzed linear regression residuals from ln-transformed length-weight (LW) relationships developed with pooled 2001 and 2003 data to examine spatial and temporal variation in body condition. This approach is equivalent to relative condition factor (LeCren 1951) without the residuals converted to percentages of a maximum value. We avoided transforming the residuals into percentages because percentages are a less desirable data format for ANOVA. We used 3-way ANOVA to test for effects of year, season (March-June versus July-October), and sampling site on the $\mathrm{LW}$ residuals.

\section{RESUlts}

We collected 587 Sacramento pikeminnow $($ mean $\mathrm{FL}=118 \mathrm{~mm}$; range $=41-463 \mathrm{~mm})$ in 299 beach seine hauls during 16 months of sampling. Ninety-four percent were $<200 \mathrm{~mm}$ (Fig. 2). We collected 30 Sacramento pikeminnow (mean FL $=352 \mathrm{~mm}$; range $=240$ $540 \mathrm{~mm}$ ) during 61 hours of gill net sampling, with at least 1 collected by gill net in 14 of 16 months sampled. An additional 923 Sacramento pikeminnow $($ mean $\mathrm{FL}=85 \mathrm{~mm}$; range $=$ 30-215 mm) were collected during the 7 years of rotary screw-trap sampling. Based on the

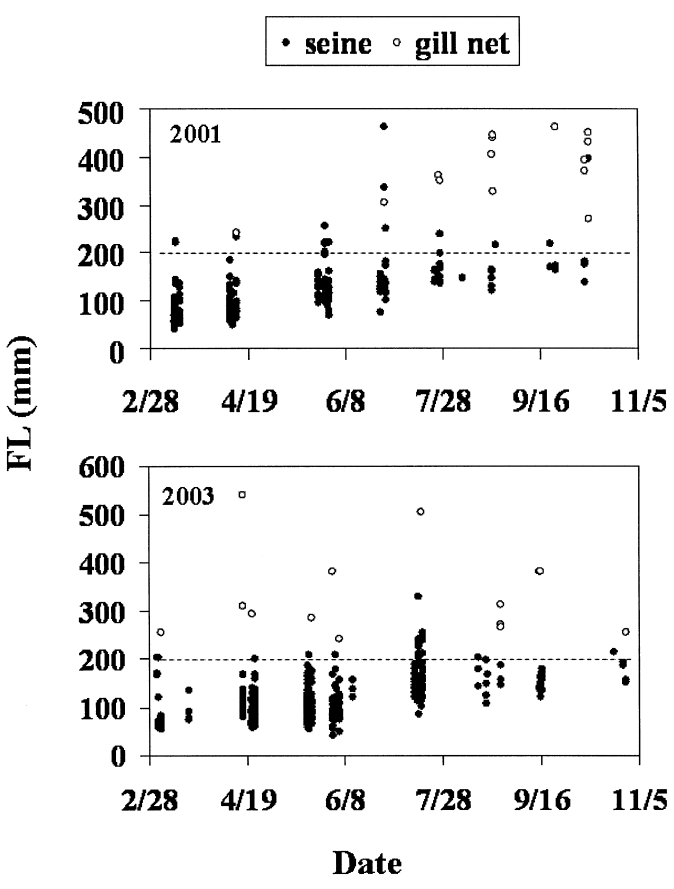

Fig. 2. Sacramento pikeminnow fork length ( $\mathrm{mm}$ ) versus date of collection for 2001 (top) and 2003 (bottom). The data are pooled from all sampling locations. The dashed lines at $200 \mathrm{~mm}$ indicate level above which beach seine efficiency declined.

observation that Sacramento pikeminnow $<50$ $\mathrm{mm}$ were not collected after March in 2001, we conclude that we did not catch any 2001year-class fish during their first growing season (Fig. 2). We may have collected small numbers of 2003-year-class fish in 2003 because 2 individuals collected in June were the smallest $(<50 \mathrm{~mm})$ Sacramento pikeminnow collected that year (Fig. 2). However, the vast majority of the Sacramento pikeminnow we collected were probably age 1 or older. Based on an equivalent analysis of the rotary screwtrap data, virtually all (99.8\%) of the Sacramento pikeminnow collected also were age 1 or older.

The growth (and possibly mortality) of Sacramento pikeminnow during our sampling seasons had a negative effect on catchability that was apparent after June or July (Fig. 2). Despite this seasonal decline in catch and the low catch of age-0 individuals, Sacramento pikeminnow were among the more common fishes collected in both years. Based on beach seine collections, Sacramento pikeminnow occurred in 
$57 \%$ of site visits in 2001 and $79 \%$ in 2003 . This ranked 7th of 36 species in 2001 and 2nd of 32 species in 2003. Average beach seine densities of Sacramento pikeminnow were 16 fish $\cdot 10,000 \mathrm{~m}^{-3}(2001)$ and $41 \mathrm{fish} \cdot 10,000 \mathrm{~m}^{-3}$ (2003). These densities also were the 7 th and 2nd highest of all fishes collected in 2001 and 2003, respectively.

Sacramento pikeminnow $<200 \mathrm{~mm}$ occurred at higher densities in 2003 than in 2001 ( $F=$ 6.41 , $\mathrm{df}=1, P=0.01)$. Density also differed among sites $(F=9.54$, df $=4, P<0.001)$, but there was no difference in density across sites between years, i.e., there was no site $x$ year interaction $(F=0.733, \mathrm{df}=4, P=0.57)$. The site effect resulted from near zero catches at Mildred Island where density was lower than at any of the other 4 sites (Tukey multiple comparison tests for unequal $n$; all $P<0.05$ ). No other between-site differences in density were detected (Tukey multiple comparison tests for unequal $n$; all $P>0.05$ ). Stream flow, as indexed by flow in Yolo Bypass, was correlated with Sacramento pikeminnow catch per unit effort as they entered the Delta through the Toe Drain (Fig. $3 ; r^{2}=0.97, \mathrm{df}=6, P=5$ $\left.\times 10^{-5}\right)$.

As with Sacramento pikeminnow $<200 \mathrm{~mm}$, the distribution and relative abundance of individuals $\geq 200 \mathrm{~mm}$ at Mildred Island $(n=0)$ was lower than at the other sites (Fig. 4). In contrast to the smaller fish, distribution of Sacramento pikeminnow $\geq 200 \mathrm{~mm}$ appeared to vary among years. In 2001, large Sacramento pikeminnow were only collected at Sacramento River sites and appeared to increase in abundance in a downstream direction. In 2003, catch was more evenly distributed among the 4 sites at which individuals were collected.

Sacramento pikeminnow ate a variety of prey (Table 1). The most commonly occurring prey for Sacramento pikeminnow $<150 \mathrm{~mm}$ were benthic invertebrates, corophiid amphipods $(78 \%)$, and annelids (26\%). A variety of fish taxa were preyed on by Sacramento pikeminnow $<150 \mathrm{~mm}$, but all prey fish taxa occurred in $\leq 4 \%$ of foreguts. Sacramento pikeminnow $\geq 150 \mathrm{~mm}$ had lower frequency of occurrence of most invertebrate prey and higher frequency of occurrence of most fish prey. Gobies and inland silverside were the most commonly eaten identifiable prey fishes. No salmonids were identified as prey items in either year.

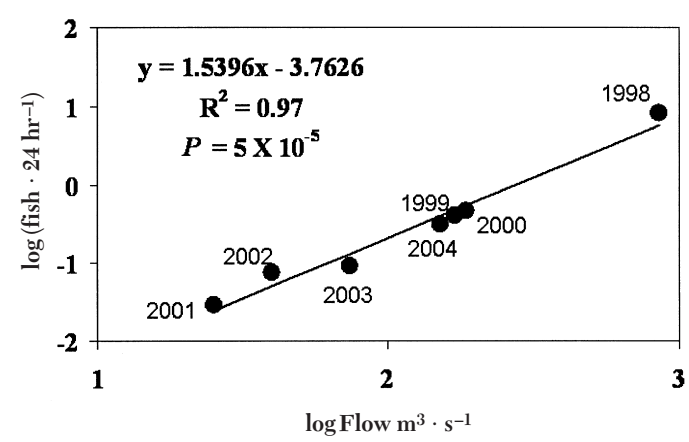

Fig. 3. Linear regression relationship between $\log _{10^{-}}$ transformed Yolo Bypass flow $\left(\mathrm{m}^{3} \cdot \mathrm{s}^{-1}\right)$ and $\log _{10}$-transformed Sacramento pikeminnow catch per unit effort (fish $.24 \mathrm{hr}^{-1}$ ) from a rotary screw trap in the Yolo Bypass Toe Drain, January-June, 1998-2004. The flow data were taken from the USGS gaging station for Yolo Bypass at Woodland, California.

The LW relationship for Sacramento pikeminnow was $\ln$ (weight $)=\ln ($ length $)(2.915)-$ $11.10\left(r^{2}=0.99, n=314\right)$. The $\mathrm{LW}$ residuals differed significantly between seasons $(F=$ 70.2 , df $=1, P<0.001$; Fig. 3 ), but not between years $(F=2.29$, df $=1, P=0.13)$, or among sites $(F=1.57, \mathrm{df}=3, P=0.20)$. None of the interaction terms were significant (all $P$ $>0.15$ ). This finding suggests body condition declined midway through both sampling seasons.

\section{Discussion}

Sacramento pikeminnow is one of the most abundant native fishes in the Sacramento-San Joaquin watershed (Moyle 2002). Our results suggest Sacramento pikeminnow may be more common in the Delta than was previously recognized. Further, the Delta may be an important rearing habitat for juvenile (age 1 and older) Sacramento pikeminnow. Our results also suggest that interannual variation in stream flows may play an important role in determining how many juvenile Sacramento pikeminnow rear in the Delta. However, the Delta does not appear to be an important rearing habitat for age-0 Sacramento pikeminnow. Dege and Brown (2004) reported the results from 7 years of larval fish sampling in the Delta and upper San Francisco Estuary. The program conducted approximately 1000 trawls per year from MarchJuly 1995-2001. During this period, only 1 larval Sacramento pikeminnow was collected. 


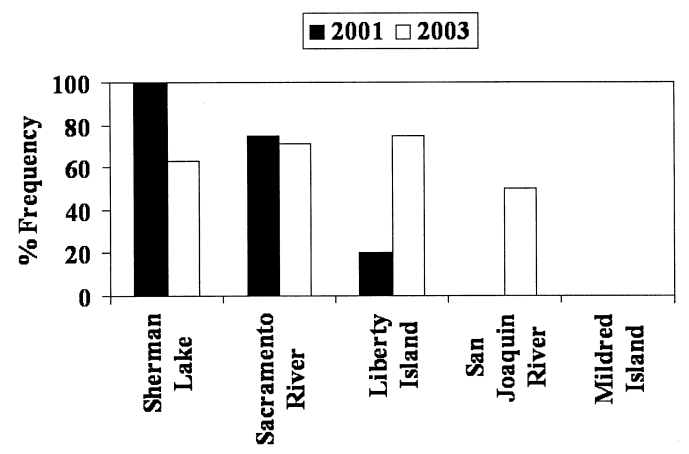

Fig. 4. The percentages of sampling dates during which Sacramento pikeminnow $\geq 200 \mathrm{~mm}$ were collected by beach seine or gill net at 5 sites in the Sacramento-San Joaquin Delta, March-October 2001 and 2003. From left to right on the $\mathrm{x}$-axis, the first 3 sites are in the Sacramento River and the latter 2 are in the San Joaquin River. Within each basin, the sites are ordered from downstream to upstream.

Sacramento pikeminnow spawn in nontidal tributaries of the Sacramento and San Joaquin rivers, and the mainstem Sacramento River above tidal influence (Taft and Murphy 1950, Brown 1990, Brown and Ford 2002). Spawning typically occurs in late spring-early summer over gravel substrates in running water (Moyle 2002). In a recent study of the Feather River (Fig. 1) Sacramento pikeminnow larvae were collected May-August (A. Seesholtz, California Department of Water Resources, personal communication). Unregulated Sacramento Basin flows are very rare from May-November. After hatching, larval Ptychocheilus spp. disperse via river flows (Gadomski and Barfoot 1998, Harvey et al. 2002), but quickly seek out suitable shallow backwater habitats (Gadomski et al. 2001, Moyle 2002). Thus, we hypothesize that spawn timing and habitat preferences of age-0 Sacramento pikeminnow facilitate their retention in natal tributaries.

Sacramento pikeminnow that migrate to the Delta as juveniles may grow faster than individuals in tributary habitats. As evidence for this hypothesis, Sacramento pikeminnow collected from a Delta location (Sacramento River at Clarksburg) had the highest reported size in a comparison of 9 California sites (Brown 1990). Fish from Clarksburg averaged $128 \mathrm{~mm}$ at formation of their 1st annulus and $221 \mathrm{~mm}$ at formation of their 2nd annulus, whereas average lengths ranged from $52-85 \mathrm{~mm}$ and 99-168 $\mathrm{mm}$ for same-age fish at the other 8 sites. We did not age the Sacramento pikeminnow we collected and we do not know their rearing history prior to Delta entry. However, most individuals appeared to have grown to sizes over $200 \mathrm{~mm}$ by late summer (Fig. 2). Thus, we think these fish were growing at rates comparable to the Clarksburg fish (Brown 1990). Note however that our results indicated that body condition detiorated significantly during summer. Therefore, the Delta may only provide a seasonal benefit to juvenile Sacramento pikeminnow.

As described above, Sacramento pikeminnow spawn in nontidal habitats. Therefore, adult Sacramento pikeminnow inhabiting the Delta must migrate upstream to spawn. However, it is not clear from our results whether sexual maturity or any other particular cue results in patterned upstream migration. Studies of Ptychocheilus spp. migratory behavior indicate there is considerable individual variation; some individuals do not move appreciable distances while others migrate tens of $\mathrm{km}$ or more (Brown 1990, Osmundson et al. 1998). In an extreme example, 1 individual adult Sacramento pikeminnow tagged in the Delta was recovered $400 \mathrm{~km}$ upstream at Red Bluff, California (Moyle 2002). Sacramento pikeminnow reach sexual maturity at 220-250 $\mathrm{mm}$ FL (Moyle 2002). Therefore, adults were fairly invulnerable to our beach seine sampling, though a few were collected in the gill net (Fig. 2). Most of the Sacramento pikeminnow collected in the gill net $(68 \%)$ were captured during the latter half of our sampling seasons (July-October). Thus, it is possible that this reflected adults returning to the Delta after spawning. However, this pattern was less pronounced in 2003 than in 2001 (Fig. 2). Additional study of Sacramento pikeminnow migrations in the Sacramento River is warranted.

To date, the major management issue involving Sacramento pikeminnow concerns predation of young salmonids (Brown and Moyle 1981). Thus, recognition of common, fast-growing Sacramento pikeminnow in the Delta could alarm salmonid managers. Although salmonid fishes were not an identified prey of Sacramento pikeminnow in this study (Table 3), our data are based on very low sample size. Further, most of the Sacramento pikeminnow we collected were not large enough to efficiently prey on juvenile salmonids. In the Columbia River basin, northern pikeminnow 
TABLE 1. Sample sizes, mean fork lengths ( $\mathrm{mm}+$ length ranges), and diet composition (percentage of guts containing each prey taxon) of age-1 and older Sacramento pikeminnow in the Sacramento-San Joaquin Delta, March through October 2001 and 2003. Diet data were divided into 2 size classes: $<150 \mathrm{~mm}$ FL and $\geq 150 \mathrm{~mm}$ FL.

\begin{tabular}{|c|c|c|}
\hline Prey taxa & $<150 \mathrm{~mm}$ & $\geq 150 \mathrm{~mm}$ \\
\hline ANNELIDS ${ }^{a}$ & 26 & 6 \\
\hline \multicolumn{3}{|l|}{ INSECTS } \\
\hline Diptera & 4 & 6 \\
\hline Heteroptera & 5 & 0 \\
\hline Odonata & 1 & 0 \\
\hline Other or unidentified & 19 & 8 \\
\hline \multicolumn{3}{|l|}{ Crustaceans } \\
\hline Microzooplankton ${ }^{\mathrm{b}}$ & 3 & 0 \\
\hline Corophiid amphipods & 78 & 20 \\
\hline Gammarid amphipods & 12 & 2 \\
\hline Isopods & 9 & 4 \\
\hline Siberian prawn (Exopalaemon modestus) & 1 & 0 \\
\hline Crayfish & 0 & 4 \\
\hline \multicolumn{3}{|l|}{ Fishes } \\
\hline Inland silverside (Menidia beryllina) & 1 & 12 \\
\hline Striped bass (Morone saxatilis) & 1 & 2 \\
\hline Prickly sculpin (Cottus asper) & 1 & 2 \\
\hline Tule perch (Hysterocarpus traski) & 0 & 2 \\
\hline Bigscale logperch (Percina macrolepida) & 0 & 2 \\
\hline Gobiidae & 4 & 12 \\
\hline Clupeidae & 3 & 4 \\
\hline Unidentified fishes & 1 & 16 \\
\hline Plant Material or DETRITUs & 4 & 14 \\
\hline TOTALS & $<150 \mathrm{~mm}$ & $\geq 150 \mathrm{~mm}$ \\
\hline Number examined & 157 & 125 \\
\hline Number with food & 78 & 49 \\
\hline Lengths of fish with empty guts & $125(72-149)$ & $230(150-504)$ \\
\hline Lengths of fish with food in gut & $107(65-148)$ & $210(151-463)$ \\
\hline
\end{tabular}

aMost identifiable remains were Neanthes limnicola.

${ }^{\mathrm{b}}$ Copepods and cladocerans

are not considered efficient predators of juvenile salmonids until they attain a length of 250 mm (Ward et al. 1995, Zimmerman 1999). It is also possible that we failed to observe predation on salmonids because adult Sacramento pikeminnow inhabit deeper water than juveniles (Brown 1990). Nonetheless, it should be noted that most Sacramento pikeminnow $\geq 200$ $\mathrm{mm}$ were collected from sites in the Sacramento River (Fig. 3; see also Turner 1966), where survival of young Chinook salmon tends to be comparatively high (Brandes and McLain 2001). Therefore, we do not think predation by Sacramento pikeminnow is a major source of mortality for Chinook salmon in the Delta.

A variety of restoration projects are being considered in the Delta and its watershed to reverse declines in native fishes. One approach being considered is the inundation of subsided agricultural lands to create tidal wetlands (Lucas et al. 2002). Although flooded islands can support high production of lower trophic levels, inundation of agricultural land can create lake-like habitats with poor circulation and extensive beds of submerged vegetation that harbor extensive nonnative centrarchid populations (Brown 2003). Sacramento pikeminnow are usually not abundant in lakes containing large centrarchid populations (Moyle 2002). This is consistent with our finding of near zero catch of Sacramento pikeminnow at Mildred Island. This hypothesis likely applies to other native species as Grimaldo et al. (2004) reported low numbers of larval native fishes from Mildred Island and similar nearby habitats.

In summary we hypothesize that some Sacramento pikeminnow disperse into the Delta at age 1 (or older), where growth appears to be relatively fast during spring and early summer. The dispersal of juveniles into the Delta may be facilitated by stream flows encountered during the 2nd (calendar) year of life. It remains unclear whether these Sacramento pikeminnow 
remain in the Delta until they reach sexual maturity. It also remains unclear whether adult Sacramento pikeminnow habitually return to the Delta after spawning. Juvenile Sacramento pikeminnow appear to successfully utilize nearshore, tidal freshwater habitat throughout much of the area studied. Sacramento pikeminnow have relatively broad environmental tolerances (Cech et al. 1990) and opportunistic feeding habits (Table 1; Brown 1990, Nakamoto and Harvey 2003). Despite their opportunistic feeding habits, we did not find evidence that Sacramento pikeminnow pose a significant threat to salmonid fishes emigrating through the Delta. Sacramento pikeminnow, like several local fish species of concern (Chinook salmon, steelhead Oncorhyncus mykiss, and splittail Pogonichthys macrolepidotus) does not complete its life cycle in the Delta and does not thrive where centrarchid fishes are abundant (Moyle 2002). Thus, adequate protection and restoration of the river-estuary continuum is essential to the continued success of Sacramento pikeminnow and other native fishes. The ability of Sacramento pikeminnow and northern pikeminnow Ptychocheilus oregonensis to thrive in modified habitats seems to contrast the endangered Colorado pikeminnow.

\section{ACKNOWLEDGMENTS}

We thank the Interagency Ecological Program for the San Francisco Estuary for funding and logistical support. In particular, we thank B. McDonnell, P. Hergesell, Z. Hymanson, T. Sommer, and M. Chotkowski for facilitating this support. Additionally, we thank J. Bandell, D. Blakeman, T. Brown, M. Dege, A. Gregory, J. Hanni, R. Mayfield, E. Santos, J. Thompson, and numerous other CDWR and CDFG staff who assisted with field and/or laboratory work for this project. T. Sommer and B. Harrell provided the data for Yolo Bypass. We thank L.R. Brown for his review of the draft manuscript. We thank K. Carp and 2 anonymous reviewers for their improvements to the submitted manuscript.

\section{Literature Cited}

Arthur, J.F., M.D. Ball, and M.Y. Baughman. 1996. Summary of federal and state water project environmental impacts in the San Francisco Bay-Delta Estuary, California. Pages 445-495 in J.T. Hollibaugh, editor, San Francisco Bay: the ecosystem. Pacific Divi- sion of the American Association for the Advancement of Science, San Francisco, CA.

Bennett, W.A., And P.B. Moyle. 1996. Where have all the fishes gone? Interactive factors producing fish declines in the Sacramento-San Joaquin Estuary. Pages 519-542 in J.T. Hollibaugh, editor, San Francisco Bay: the ecosystem. Pacific Division of the American Association for the Advancement of Science, San Francisco, CA.

Bayley, P.B., and R.A. Herendeen. 2000. The efficiency of a seine net. Transactions of the American Fisheries Society 129:901-923.

BotTom, D.L., AND K.K. Jones. 1990. Species composition, distribution, and invertebrate prey of fish assemblages in the Columbia River Estuary. Progress in Oceanography 25:243-270.

Brandes, P.L., AND J.S. MCLaIn. 2001. Juvenile Chinook salmon abundance, distribution, and survival in the Sacramento-San Joaquin Estuary. Pages 39-138 in R.L. Brown, editor, Contributions to the biology of Central Valley salmonids. Volume 2. California Department of Fish and Game Fish Bulletin 179.

Brown, L.R. 1990. Age, growth, feeding, and behavior of Sacramento squawfish (Ptychocheilus grandis) in Bear Creek, Colusa Co., California. Southwestern Naturalist 35:249-260.

2003. Will tidal wetland restoration enhance populations of native fishes? San Francisco Estuary and Watershed Science 1. Available from: http://repositories.cdlib.org/jmie/sfews/.

BROwn, L.R., AND T. FORD. 2002. Effects of flow on the fish communities of a regulated California river: implications for managing native fishes. River Research and Applications 18:331-342.

Brown, L.R., AND P.B. MoYLE. 1981. The impact of squawfish on salmonid populations: a review. North American Journal of Fisheries Management 1:104-111.

. 1991. Changes in habitat and microhabitat partitioning within an assemblage of stream fishes in response to predation by Sacramento squawfish (Ptychocheilus grandis). Canadian Journal of Fisheries and Aquatic Sciences 48:849-856.

Carney, D.A., AND L.M. Page. 1990. Meristic characteristics and zoogeography of the genus Ptychocheilus (Teleostei: Cyprinidae). Copeia 1990:171-181.

Cech, J.J., Jr., S.J. Mitchell, D.T. Castleberry, and M. McEnroe. 1990. Distribution of California stream fishes: influence of environmental temperature and hypoxia. Environmental Biology of Fishes 29:95-105.

Dege, M., And L.R. BRown. 2004. Effect of outflow on spring and summertime distribution and abundance of larval and juvenile fishes in the upper San Francisco Estuary. Pages 49-66 in F. Feyrer, L.R. Brown, R.L. Brown, and J.J. Orsi, editors, Early life history of fishes in the San Francisco Estuary and watershed. American Fisheries Society Symposium 39.

Gadomski, D.M., and C.A. Barfoot. 1998. Diel and distributional abundance patterns of fish embryos and larvae in the lower Columbia and Deschutes Rivers. Environmental Biology of Fishes 51:353-368.

Gadomski, D.M., C.A. Barfoot, J.M. Bayer, and T.P. Poe. 2001. Early life history of the northern pikeminnow in the lower Columbia River basin. Transactions of the American Fisheries Society 130:250-262.

Grimaldo, L.F., R.E. Miller, C.M. Peregrin, and Z.P. HyMANSON. 2004. Spatial and temporal distribution of native and alien ichthyoplankton in 3 habitat types 
of the Sacramento-San Joaquin Delta. Pages 81-96 in F. Feyrer, L.R. Brown, R.L. Brown, and J.J. Orsi, editors, Early life history of fishes in the San Francisco Estuary and watershed. American Fisheries Society Symposium 39.

Harvey, B.C., J.L. White, and R.J. Nakamoto. 2002. Habitat relationships and larval drift of native and nonindigenous fishes in neighboring tributaries of a coastal California river. Transactions of the American Fisheries Society 131:159-170.

Kimmerer, W.J. 2002. Physical, biological, and management responses to variable freshwater flow into the San Francisco Estuary. Estuaries 25:1275-1290.

LE Cren, E.D. 1951. The length-weight relationship and seasonal cycle in gonad weight and condition in the perch Perca fluviatilis. Journal of Animal Ecology 20:201-219.

Lucas, L.V., J.E. Cloern, J.K. Thompson, and N.E. MonSEN. 2002. Functional variability of habitats within the Sacramento-San Joaquin Delta: restoration implications. Ecological Applications 12:1528-1547.

Matern, S.A., P.B. Moyle, And L.C. Pierce. 2002. Native and alien fishes in a California estuarine marsh: twenty-one years of changing assemblages. Transactions of the American Fisheries Society 131:797-816.

Merz, J.E., AND C.D. Vanicek. 1996. Comparative feeding habits of juvenile chinook salmon, steelhead, and Sacramento squawfish in the lower American River, California. California Fish and Game 82:149-159.

Moyle, P.B. 2002. Inland fishes of California: revised and expanded. University of California Press, Berkeley. $502 \mathrm{pp}$.

Moyle, P.B., P.K. Crain, K. Whitener, and J.F. Mount. 2003. Alien fishes in natural streams: fish distribution, assemblage structure, and conservation in the Cosumnes River, California, USA. Environmental Biology of Fishes 68:143-162.

Nakamoto, R.J., And B.C. Harvey. 2003. Spatial, seasonal, and size-dependent variation in the diet of Sacramento pikeminnow in the Eel River, northwestern California. California Fish and Game 89:30-45.
Osmundson, D.B., R.J. Ryel, M.E. Tucker, D.B. Burdick, W.R. Emblad, and T.E. Chart. 1998. Dispersal patterns of subadult and adult Colorado squawfish in the upper Colorado River. Transactions of the American Fisheries Society 127:943-956.

Sommer, T.R., W.C. Harrell, R. Kurth, F. Feyrer, S.C. ZeUG, AND G.O. O'Leary. 2004. Ecological patterns of early life stages of fishes in a large river-floodplain of the San Francisco Estuary. Pages 111-124 in F. Feyrer, L.R. Brown, R.L. Brown, and J.J. Orsi, editors, Early life history of fishes in the San Francisco Estuary and watershed. American Fisheries Society Symposium 39.

TaFt, A.C., And G.I. Murphy. 1950. Life history of the Sacramento squawfish (Ptychocheilus grandis). California Fish and Game 36:147-164.

Turner, J.L. 1966. Distribution of cyprinid fishes in the Sacramento-San Joaquin Delta. Pages 154-159 in J.L. Turner and D.W. Kelley, compilers, Ecological studies of the Sacramento-San Joaquin Delta. Part II: Fishes of the Delta. California Department of Fish and Game Fish Bulletin 136.

VondraceK, B., D. Baltz, L.R. Brown, and P.B. Moyle. 1989. Spatial, seasonal, and diel distribution of fishes in a California reservoir dominated by native fishes. Fisheries Research 7:31-53.

Ward, D.L., J.H. Petersen, and J.J. Loch. 1995. Index of predation on juvenile salmonids by northern squawfish in the lower and middle Columbia River and in the lower Snake River. Transactions of the American Fisheries Society 124:321-334.

Zimmerman, M.P. 1999. Food habits of smallmouth bass, walleyes, and northen pikeminnow in the lower Columbia River basin during outmigration of juvenile anaromous salmonids. Transactions of the American Fisheries Society 128:1036-1054.

Received 16 September 2004 Accepted 18 February 2005 